\title{
O poeta Machado de Assis
}

\author{
Adilson Citelli* \\ Professor livre-docente no Departamento de Comunicações e Artes \\ da ECA-USP e chefe do Departamento de Comunicações e Artes. \\ E-mail: citelli@uol.com.br
}

Machado de Assis, considerado a partir do final do século XX como o maior romancista brasileiro, foi um dos fundadores e presidente da Academia Brasileira de Letras. Obteve projeção mundial com a tradução de suas principais obras para vários idiomas; críticos como Harold Bloom (Estados Unidos), John Gledson (Inglaterra), Anatole France (França) e Susan Sontag (Estados Unidos), entre muitos outros, têm feito da obra machadiana objeto de seus estudos. É conhecido e exaltado por sua ficção, sobretudo pela tríade Memórias Póstumas de Brás Cubas (1881), Quincas Borba (1891) e Dom Casmurro (1899), todas impregnadas de registros do seu mais fino e inconfundível estilo: desilusão, sarcasmo e amargor. Embora tenha ficado na memória dos leitores por meio de seus romances e contos, Machado foi também cronista, dramaturgo, ensaísta, crítico e poeta.

\section{REPRESENTAÇÕES NA CULTURA}

Machado de Assis já foi retratado no cinema, interpretado por Jaime Santos no filme Vendaval Maravilhoso (1949) e Ludy Montes Claros no filme Brasília 18\% (2006). Também teve sua efígie impressa nas notas de NCz\$1,00 (um Cruzado Novo, até 1989, com valor de mil cruzados) de 1987. Importantes concursos são criados em todo o mundo levando seu nome, a exemplo de Brasília, realizado pelo SESC-DF.

A revista Comunicação \& Educação, por ocasião do centenário da morte de Machado de Assis (1839-1908), presta-lhe uma homenagem. De sua fecunda obra, pretendemos apresentar ao leitor uma face do grande ficcionista brasileiro desconhecida por muitos: o poeta Machado de Assis. Ainda que a sua poesia não apresente a sagacidade e a complexidade do pensamento de sua ficção, não deve jamais ser relegada já que, como filha de um gênio, relampeja suas características.

* Com a colaboração de Cristine Vargas (FFLCH/ USP). 
comunicação \& educação • Ano XIII • Número 2 - maio/ago 2008

\section{BIOGRAFIA}

Joaquim Maria Machado de Assis nasceu no Morro do Livramento, no Rio de Janeiro, em 1839. Filho de um pintor mulato e de uma lavadeira açoriana, tornou-se órfão de ambos muito cedo, sendo criado pela madrasta Maria Inês. Já na infância foi acometido de epilepsia e gaguez, males que o acompanhariam durante toda a vida e que lhe dariam uma feição tímida e reservada. Seus primeiros estudos foram realizados em escola pública e acompanhados por um padre amigo, Silveira Sarmento, que lhe ministrou aulas de francês e latim. Entretanto, foi como autodidata que o escritor solidificou sua vasta cultura literária, que incluía renomados escritores internacionais. Seu primeiro ofício foi exercido como aprendiz de tipógrafo na Imprensa Nacional; pouco tempo depois, foi admitido no Correio Mercantil. Em 1860, através de Quintino Bocaiúva, foi introduzido no Diário do Rio de Janeiro, para o qual fazia resenhas dos debates do Senado usando uma linguagem sarcástica. Aos trinta anos de idade, casou-se com Carolina Xavier de Novais, que seria sua companheira até a morte. Sua figura inspirou a personagem Dona Carmo, de Memorial de Aires.

Posteriormente, ascendeu na carreira de servidor público, primeiro no Diário Oficial (1867-1873) e, a partir de 1874, no Ministério da Agricultura, Comércio e Obras Públicas como primeiro-oficial, aposentando-se no cargo de diretor do Ministério da Viação e Obras Públicas. Amparado pela carreia burocrática, pôde dedicar-se à vocação de escritor. Entre 1870 e 1880 foram publicados Contos Fluminenses (1870), Ressurreição (1872), Histórias da Meia-Noite (1873), A Mão e a Luva (1874) Helena (1876) e Iaiá Garcia (1878). A partir de Memórias Póstumas de Brás Cubas (1881), Machado de Assis atinge a maturidade como escritor realista, característica manifestada nas obras subseqüentes: Histórias sem Data (1884), Quincas Borba (1891), Várias Histórias (1896), Páginas Recolhidas (1899), Dom Casmurro (1900), Esaú e Jacó (1904) e Relíquias da Casa Velha (1906). O último romance, Memorial de Aires (1906), foi escrito após a morte de Carolina. Dois anos depois o escritor foi vítima de uma úlcera maligna, falecendo aos 69 anos.

\section{SOBRE A POESIA DE MACHADO DE ASSIS}

A primeira manifestação literária de Machado de Assis foi feita justamente através da poesia: aos 16 anos, publicou o poema Ela, no periódico A Marmota. A partir desta fase, até os 25 anos, produziu apenas obras teatrais. Somente em 1864 publicou Crisálidas, seu primeiro livro de poesias. Seis anos depois vem a público Falenas, mesmo ano em que são publicados os Contos Fluminenses. Crisálidas e Falenas apresentam uma mistura de lirismo e parnasianismo; líricos em seus temas e parnasianos por buscarem o preciosismo na forma. Em 1875, publica Americanas, que mostra influências do célebre escritor romântico José de Alencar, que acreditava, como tantos outros de sua época, estar no 
elemento indígena a genuína poesia brasileira. Em 1901, o escritor publica Poesias Completas, uma coletânea de poesias que reúne suas obras anteriores, e a então inédita Ocidentais. Nesta última, já estavam esboçadas as características realistas do autor, como a ironia e o niilismo ante o código de aparências a que os homens se impõem na sociedade.

Os poemas apresentados a seguir foram todos escritos em sua maturidade. A Mosca Azul, Círculo Vicioso e Suave Mari Magno retratam o escritor irônico, analítico e mordaz; já Carolina é um soneto pleno de lirismo e beleza dedicado à esposa falecida.

\section{A mosca azul}

Era uma mosca azul, asas de ouro e granada, Filha da China ou do Indostão.

Que entre as folhas brotou de uma rosa encarnada.

Em certa noite de verão.

E zumbia, e voava, e voava, e zumbia,

Refulgindo ao clarão do sol

E da lua - melhor do que refulgiria

Um brilhante do Grão-Mogol.

Um poleá que a viu, espantado e tristonho,

Um poleá lhe perguntou:

- "Mosca, esse refulgir, que mais parece um sonho,

Dize, quem foi que te ensinou?".

Então ela, voando e revoando, disse:

— "Eu sou a vida, eu sou a flor

Das graças, o padrão da eterna meninice,

E mais a glória, e mais o amor".

E ele deixou-se estar a contemplá-la, mudo

E tranqüilo, como um faquir,

Como alguém que ficou deslembrado de tudo,

Sem comparar, nem refletir.

Entre as asas do inseto a voltear no espaço,

Uma coisa me pareceu

Que surdia, com todo o resplendor de um paço,

Eu vi um rosto que era o seu. 
Era ele, era um rei, o rei de Cachemira, Que tinha sobre o colo nu

Um imenso colar de opala, e uma safira

Tirada ao corpo de Vichnu.

Cem mulheres em flor, cem nairas superfinas,

Aos pés dele, no liso chão,

Espreguiçam sorrindo as suas graças finas,

E todo o amor que têm lhe dão.

Mudos, graves, de pé, cem etíopes feios,

Com grandes leques de avestruz,

Refrescam-lhes de manso os aromados seios.

Voluptuosamente nus.

Vinha a glória depois; - quatorze reis vencidos, E enfim as páreas triunfais

De trezentas nações, e os parabéns unidos

Das coroas ocidentais.

Mas o melhor de tudo é que no rosto aberto

Das mulheres e dos varões,

Como em água que deixa o fundo descoberto,

Via limpos os corações.

Então ele, estendendo a mão calosa e tosca.

Afeita a só carpintejar,

Com um gesto pegou na fulgurante mosca,

Curioso de a examinar.

Quis vê-la, quis saber a causa do mistério.

E, fechando-a na mão, sorriu

De contente, ao pensar que ali tinha um império,

E para casa se partiu.

Alvoroçado chega, examina, e parece

Que se houve nessa ocupação

Miudamente, como um homem que quisesse

Dissecar a sua ilusão.

Dissecou-a, a tal ponto, e com tal arte, que ela,

Rota, baça, nojenta, vil

Sucumbiu; e com isto esvaiu-se-lhe aquela

Visão fantástica e sutil. 
Hoje quando ele aí cai, de áloe e cardamomo Na cabeça, com ar taful

Dizem que ensandeceu e que não sabe como Perdeu a sua mosca azul.

\section{Círculo vicioso}

Bailando no ar, gemia inquieto vagalume:

"Quem me dera que eu fosse aquela loira estrela Que arde no eterno azul, como uma eterna vela!"

Mas a estrela, fitando a lua, com ciúme:

"Pudesse eu copiar-te o transparente lume,

Que, da grega coluna à gótica janela,

Contemplou, suspirosa, a fronte amada e bela"

Mas a lua, fitando o sol com azedume:

"Mísera! Tivesse eu aquela enorme, aquela

Claridade imortal, que toda a luz resume!"

Mas o sol, inclinando a rútila capela:

Pesa-me esta brilhante auréola de nume...

Enfara-me esta luz e desmedida umbela...

Por que não nasci eu um simples vagalume?"...

\section{Suave Mari Magno}

Lembra-me que, em certo dia,

$\mathrm{Na}$ rua, ao sol de verão,

Envenenado morria

Um pobre cão.

Arfava, espumava e ria,

De um riso espúrio e bufão,

Ventre e pernas sacudia

$\mathrm{Na}$ convulsão.

Nenhum, nenhum curioso

Passava, sem se deter,

Silencioso,

Junto ao cão que ia morrer,

Como se lhe desse gozo

Ver padecer. 
comunicação \& educação • Ano XIII • Número 2 - maio/ago 2008

\section{Carolina}

Querida, ao pé do leito derradeiro

Em que descansas dessa longa vida, Aqui venho e virei, pobre querida, Trazer-te o coração do companheiro.

Pulsa-lhe aquele afeto verdadeiro Que, a despeito de toda a humana lida, Fez a nossa existência apetecida E num recanto pôs o mundo inteiro.

Trago-te flores - restos arrancados Da terra que nos viu passar unidos

E ora mortos nos deixa e separados.

Que eu, se tenho nos olhos malferidos Pensamentos de vida formulados, São pensamentos idos e vividos.

\section{REFERÊNCIAS BIBLIOGRÁFICAS}

ASSIS, Machado de. Machado de Assis: poesia / por Péricles Eugênio da Silva Ramos. Rio de Janeiro: Agir, 1964.

Poesias completas. Rio de Janeiro/São Paulo: W. M. Jackson, 1938.

BOSI, Alfredo. História concisa da literatura brasileira. São Paulo: Cultrix, 2001.

HADDAD, Jamil Almansur. Poemas de amor de Machado de Assis. Introdução, organização e seleção de Jamil Almansur Haddad. Rio de Janeiro: Civilização Brasileira, 1970.

\section{Endereço eletrônico}

Machado de Assis. Disponível em: <http://pt.wikipedia.org/wiki/Machado_de_ Assis $>$. Acesso em: 28 de fevereiro de 2007. 